\title{
АЛГОРИТМ I ПРОГРАМНЕ ЗАБЕЗПЕЧЕННЯ ДЛЯ ARDUINO-СИСТЕМИ ТЕСТУВАННЯ ФОТОЕЛЕКТРИЧНИХ МОДУЛІВ
}

\author{
О.Ю. Гаєвський ${ }^{1,2}$, В.Ю. Іванчук ${ }^{1,2}$, І.О. Корніснко ${ }^{1}$, В.В. Бодняк ${ }^{2}$ \\ ${ }^{1}$ Національний технічний університет України «Київський політехнічний інститут ім. Ігоря Сікорського», \\ 03056, пр-т. Перемоги, 37, м. Київ, Україна, \\ ${ }^{2}$ Інститут відновлюваної енергетики НАН України, \\ 02094, вул. Гната Хоткевича, 20А, м. Київ, Україна.
}

В роботі представлено реалізацію програмного забезпечення та алгоритмів роботи для вимірювально-обчислювальної системи, щзо призначена для визначення в реальних умовах електричних характеристик фотоелектричних модулів методом змінного активного навантаження. Описано програмне забезпечення для пакета МАТLАВ, яке включає в себе користувацький інтерфейс та алгоритми управління процесом вимірювання вольт-амперних характеристик. Користувачький інтерфейс розроблений за допомогою пакета розширення MATLAB Support Package for Arduino Hardware. Це програмне забезпечення дозволяє проводити велику кількість вимірів у різних режимах з опціональним підключенням піранометра та заданням необхідної затримки між відліками, відображати ВАХ і потужнісну характеристику та основні параметри ФМ, зберігати дані та здійснювати менеджмент уже збережених даних, контролювати прочес поточного виміру, проводити діагностику системи. Використання цієї системи актуально для тестування та діагностики поточного стану фотомодулів у польових умовах, визначення фактичних електричних параметрів фотомодулів. Слід зазначити, щэо ичі параметри не надаються в повному обсязі виробниками, але вони суттєві для задач діагностики фотомодулів у складі фотоелектричних станцій, і пери за все - для оцінювання електричних втрат, обумовлених процесами деградації модулів. Вимірювальна схема вольт-амперних характеристик фотомодулів реалізована на базі мікроконтролерної плати Агdиіпо Mеgа 2560, яка здійснює комутацію резисторів навантаження електронними реле, збір та передачу експериментальних даних на ПК через послідовний порт. Елементи схеми заміщення фотоелектричних модулів розраховуються за допомогою оригінального методу розв'язання системи нелінійних рівнянь за стійким ітераційним алгоритмом, який заснований на розкладанні нелінійних рівнянь за малими параметрами. Бібл. 7, рис. 4.

Ключові слова: фотоелектричний модуль, вольт-амперна характеристика, схема заміщення фотомодуля, визначення параметрів фотомодуля.

\section{ALGORITHM AND SOFTWARE FOR ARDUINO-BASED SYSTEM FOR PV MODULE TESTING}

\author{
A. Gaevskii ${ }^{1,2}$, V. Ivanchuk ${ }^{1,2}$, I. Kornienko ${ }^{1}$, V. Bodnyak ${ }^{2}$ \\ ${ }^{1}$ National Technical University of Ukraine «Igor Sikorsky Kyiv Polytechnic Institute», \\ 03056, 37 Peremogy Av., Kyiv, Ukraine. \\ ${ }^{2}$ Institute of Renewable Energy of the National Academy of Sciences of Ukraine, \\ 02094, 20A Hnata Khotkevycha St., Kyiv, Ukraine.
}

The work presents the implementation of software and algorithms for measuring and computing system, which is designed to determine in real conditions the electrical characteristics of photovoltaic modules by the method of variable active load. The software for the MATLAB package is described, which includes a user interface and algorithms for controlling the process of measuring currentvoltage characteristics. The user interface was developed using the MATLAB Support Package for Arduino Hardware.

This software allows to perform a large number of measurements in different modes with optional connection of the pyranometer and set the required delay between readings, display I-V characteristics and power characteristics and basic parameters of FM, store data and manage already stored data, control the current measurement process, system diagnostics. Using of this system is actual for testing the current state of PV modules in field conditions, for correct determination of electrical parameters of modules. It should be noted that these parameters are not provided in full by the manufacturers, but they are essential for the diagnostics of modules on PV plants. Knowledge of the module parameters is also necessary for correct solution of optimization problems under design of PV system and for prediction of energy output in different external conditions.

The measurement of current-voltage characteristics of PV modules is realized on the basis of the microcontroller board Arduino Mega 2560, which provides switching of load resistors with electronic relays, collection and transfer of experimental data to PC by the serial

(C) О.Ю. Гаєвський, В.Ю. Іванчук, І.О. Корнієнко, В.В. Бодняк, 2021 
port. The elements of the equivalent scheme of PV modules are calculated by the original method for solving of nonlinear equations system by a stable iterative algorithm, which is based on the decomposition of nonlinear equations on the small parameters. A number of measurements at various solar radiation and temperature was performed and dependencies of the main PV module parameters on external factors were determined. Ref. 7, fig. 4.

Keywords: PV module, current-voltage characteristic, partial shading, determination of PV module parameters.

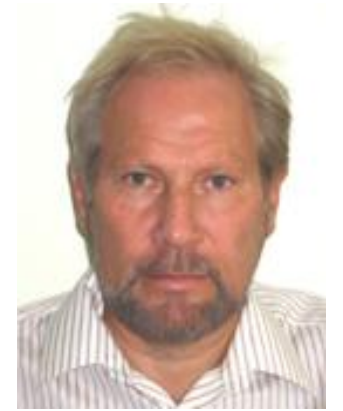

О.Ю. Гаєвський A. Gaevskii

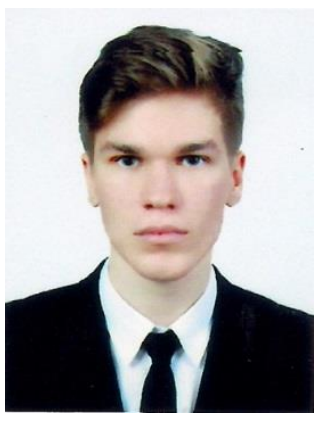

B.Ю. Іванчук V. Ivanchuk

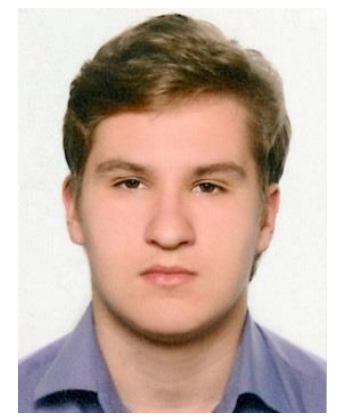

I.O. Корнієнко I. Korniienko

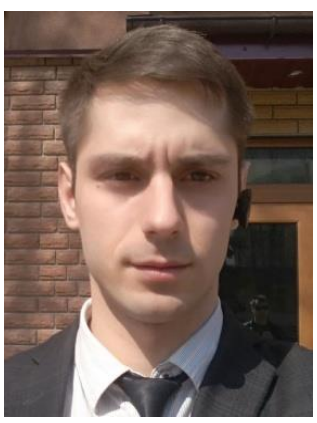

B.В. Бодняк

V. Bodnyak
Відомості про автора: д-р фіз.-мат. наук, професор кафедри ВДЕ

Освіта: НТУУ «Київський політехнічний інститут ім. Ігоря Сікорського»

Наукова сфера: відновлювана енергетика, фотоелектричні системи, комп'ютерне моделювання

Публікації: 125

ORCID: 0000-0001-6144-2441

Контакти: тел.: +38(097)570-46-43

e-mail: a.gaevskii@kpi.ua

Відомості про автора: студент НТУУ «Київський політехнічний інститут ім. Ігоря Сікорського», провідний інженер відділу № 1 Комплексних енергосистем Інституту відновлюваної енергетики НАН України Освіта: студент 6-го курсу кафедри відновлюваних джерел енергії факультету електроенерготехніки та автоматики НТУУ «Київський політехнічний інститут ім. Ігоря Сікорського»

Наукова сфера: відновлювана енергетика Публікації: 17

ORCID: 0000-0002-0585-9610

Контакти: тел: +38(096)533-03-86

e-mail: vlad.ivanchuk.13@gmail.com

Відомості про автора: студент НТУУ

«Київський політехнічний інститут ім. Ігоря Сікорського»

Освіта: студент 6-го курсу кафедри відновлюваних джерел енергії факультету електроенерготехніки та автоматики НТУУ «Київський політехнічний інститут ім. Ігоря Сікорського»

Наукова сфера: відновлювана енергетика

Публікації: 5

ORCID: 0000-0001-7856-5544

Контакти: тел.: +38(050)357-30-37

e-mail: ivan.korniienko@outlook.com

Відомості про автора: аспірант Інституту відновлюваної енергетики НАН України Освіта: НТУУ «Київський політехнічний інститут ім. Ігоря Сікорського»

Наукова сфера: відновлювана енергетика, проєктування та інсталяція фотоелектричних систем

Публікації: 5

ORCID: 0000-0002-5605-090X

Контакти: тел.: +38(067)736-72-44

e-mail: vasyl.bodniak@gmail.com
Autor information: doctor of phys. math. sci., Professor of the RES Department

Education: NTUU «Igor Sikorsky Kyiv

Polytechnic Institute»

Research area: renewable energy, PV

systems, computer simulation

Publications: 125

ORCID: 0000-0001-6144-2441

Contacts: tel.: +38(097)570-46-43

e-mail: a.gaevskii@kpi.ua

Autor information: student of NTUU «Igor Sikorsky Kyiv Polytechnic Institute», leading engineer of Department №1 of Complex Power Systems of the Institute of Renewable Energy of the NAS of Ukraine

Education: student of 6th course of the Department Renewable Energy Sources of Faculty of Electric Power Engineering and Automatics of the National Technical University of Ukraine "Igor Sikorsky Kyiv Polytechnic Institute"

Research area: renewable energy.

Publications: 17

ORCID: 0000-0002-0585-9610

Contacts: tel: +38(096)533-03-86 e-mail: vlad.ivanchuk.13@gmail.com

Autor information: student of NTUU «Igor Sikorsky Kyiv Polytechnic Institute» Education: student of 6th course of the Department Renewable Energy Sources of Faculty of Electric Power Engineering and Automatics of the National Technical University of Ukraine "Igor Sikorsky Kyiv Polytechnic Institute"

Research area: renewable energy

Publications: 5

ORCID: 0000-0001-7856-5544

Contacts: +38 (050) 357-30-37

e-mail: ivan.korniienko@outlook.com

Autor information: postgraduate Renewable Energy Institute, NAS of Ukraine Education: NTUU «Igor Sikorsky Kyiv Polytechnic Institute»

Research area: renewable energy, designing and installation of PV systems

Publications: 5

ORCID: 0000-0002-5605-090X

Contacts: tel.:+38(067)736-72-44

e-mail: vasyl.bodniak@gmail.com 
Перелік використаних позначень та скорочень:

ФМ - фотоелектричний модуль;

ККД - коефіцієнт корисної дії;

$\mathrm{XX}$ - холостий хід;

КЗ - коротке замикання;

Вступ і постановка задачі. В теперішній час у складі енергосистеми країни перебуває багато мережевих фотоелектричних станції (ФЕС) 3 встановленою потужністю понад $10 \mathrm{MBT}$, а також малопотужних ФЕС ( $<30$ кВт). Величезна кількість фотоелектричних модулів (ФМ) забезпечують генерацію електроенергії на діючих ФЕС, i однією 3 основних проблем в їх експлуатації $\epsilon$ поступове падіння електричних характеристик ФМ внаслідок певних природних процесів [1]. Тому постає необхідність проведення масового тестування фотомодулів у реальних умовах експлуатації, а отже, стрімко зростає попит на спеціалістів 3 перевірки та ремонту «сонячних панелей» [2].

Системи тестування ФМ розробляються відповідно до вимог, сформульованих у ряді стандартів [3, 4] (наприклад, ЕС 62446:2009, IEC 60364-6, NEN 1010/NTA 8013). Для оптимізації процесів встановлення і подальшої діагностики модулів багато компаній пропонують обладнання для тестування, яке дає змогу виконати вимірювання як електричних характеристик й ефективності фотоелектричної системи, так і інтенсивності радіації (наприклад, PV200, Z200 PV Analyzer, MI 3108PS, EazyPV та інші). За допомогою PV-тестерів можна безпосередньо вимірювати перелічені вище параметри, але провести аналіз отриманих залежностей (наприклад, ВАХ) i визначення більш широкого набора параметрів ФМ здебільшого неможливо. Для виконання цих задач потрібне програмне й математичне забезпечення, яке в комерційних моделях тестерів відсутнс. Тому актуальною задачею $\epsilon$ організація інтерфейсу вимірювального обладнання 3 достатньо потужною обчислювальною системою.

Ця робота присвячена розвитку вимірювальної системи на основі мікроконтролерної плати Arduino Mega [5] для
ВАХ - вольт-амперна характеристика;

АЦП - аналогово-цифровий перетворювач;

ФЕК - фотоелектрична комірка.

визначення

електричних

характеристик фотоелектричних модулів у реальних умовах експлуатації. В статті описано програмне забезпечення для пакета MATLAB, яке включає в себе користувацький інтерфейс та алгоритми управління процесом вимірювання вольтамперних характеристик (BAX). Користувацький інтерфейс розроблений за допомогою пакета розширення MATLAB Support Package for Arduino Hardware, який забезпечує доступ до математичних функцій MATLAB i дає змогу реалізувати пряме управління мікроконтролерною платою $з$ комп'ютера через дротовий USB або Wi-Fi.

Мета і задача роботи. Мета роботи удосконалення створеної раніше автоматизованої системи вимірювання ВАХ фотоелектричних модулів [5]. Задачею цієї роботи була розробка програми управління процесами вимірювання $\mathrm{i}$ обробки даних із користувацького інтерфейсу, створеного в пакеті розширення MATLAB Support Package for Arduino Hardware. Метою цього є:

- робота в єдиному інтерфейсі без використання середовища розробки Arduino;

- адаптивне налагодження умов вимірювання та обробка експериментальних даних функціональними засобами MATLAB.

Матеріали досліджень i результати розробки. Для вимірювання вольт-амперної характеристики фотоелектричних модулів у реальних польових умовах нами був розроблений вимірювальний прилад, в основі якого лежить плата Arduino Mega 2560. Мікроконтролер керує 16 електромагнітними реле, до кожного 3 яких відповідно підключений свій опір навантаження. Надійне і точне вимірювання струму та напруги здійснюється за допомогою двох 16-бітних аналогово-цифрових перетворювачів, які передають дані на Arduino по шині $\mathrm{I}^{2} \mathrm{C}$. 
Авторами було розроблене програмне забезпечення для управління 3 середовища MATLAB мікроконтролером на платформі Arduino Mega 2560, яке дає змогу виконувати вимірювання ВАХ з достатньо високою точністю в реальних польових умовах. Попередній досвід використання програмної оболонки Arduino IDE дав змогу виявити такі проблеми:

- в разі потреби внесення змін у програмний код доводиться заново програмувати ПЗУ та перезавантажувати плату;

- відсутні можливості прямого контролю мікроконтролерної плати з комп'ютера;

- неможливе візуальне представлення отриманих даних одразу після виміру;

- ускладнено пошук та перевірку несправностей.

Тому для розв'язання вищезазначених проблем доцільно використати систему управління і моніторингу плат Arduino на основі програмного середовища MATLAB. Використання MATLAB для програмування контролера Arduino відкриває доступ до функцій з вирішення різноманітних чисельних задач.
В пакеті розширення Support Package for Arduino Hardware за допомогою модуля App Designer було розроблено програмне забезпечення для керування вимірювальним приладом та відповідний графічний інтерфейс (рис.1). Результати вимірювань автоматично зберігаються у текстовому файлі на комп'ютері й відображаються в окремому вікні в режимі реального часу. В системі передбачено підключення піранометра для вимірювання інтенсивності сонячної радіації та можливість відразу вводити поправки при обчисленні ВАХ. В основному вікні програми, показаному на рис. 1 , відображаються:

- графік ВАХ у вигляді експериментальних точок та апроксимуючої модельної кривої;

- таблиця отриманих даних $V, I$;

- ряд індикаторів, які відображають замкнені і розімкнуті реле;

- поле $з$ показниками основних параметрів модуля;

- індикатор стану підключення ПК до мікроконтролерної плати;

- перемикач для підключення піранометра для вимірювання рівня сонячної радіації.

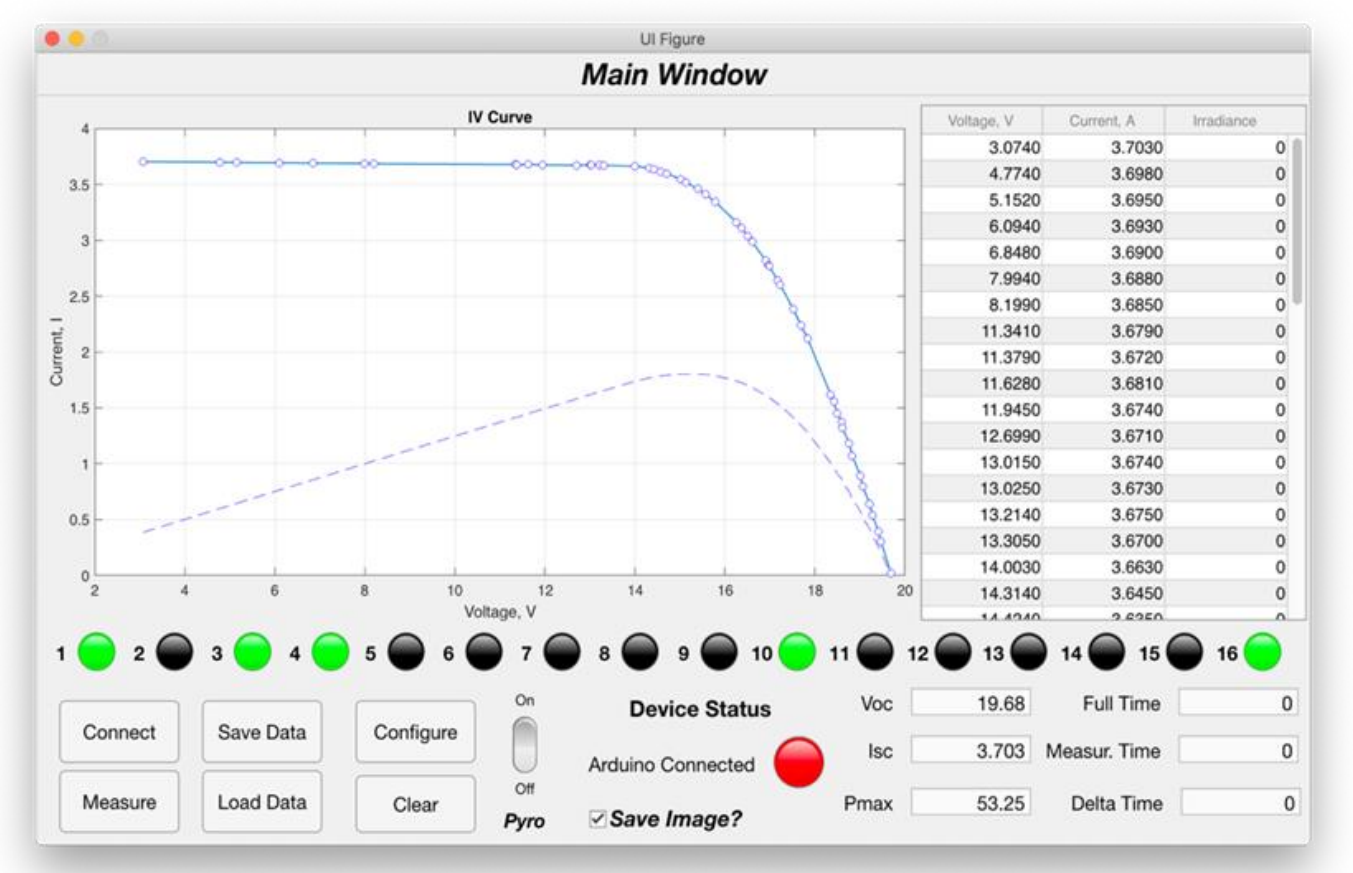

Рис. 1. Інтерфейс основного вікна ПЗ для управління вимірювальною системою

Fig. 1. The interface of the main software window to control the measuring system 
Використання MATLAB також дозволяє підключатися до плат Arduino через бездротовий зв'язок Bluetooth чи $\mathrm{Wi}-\mathrm{Fi}$, або по протоколу TCP/IP через інтернет, якщо плата підключена до Ethernet кабелю. Окремою перевагою системи MATLAB $\epsilon$ можливість керувати одночасно декількома платами Arduino, розширюючи можливості моніторингу декількох систем, підключень і управління.

Після підключення плати до програми i натискання на кнопку Measure відбувається ряд операцій згідно з алгоритмом, наведеним на блоксхемі (рис. 2). При конфігуруванні АЦП налаштовується підсилення напруги, частота обробки даних і канал, 3 якого відбувається вимірювання напруги. Далі починаються власне вимірювання ВAX фотомодуля. При цьому залежно від вибраного режиму реле перемикаються або послідовно, або за заздалегідь сформованим файлом, де зазначені потрібні комбінації включених реле для більш поступової зміни навантаження. Після кожного перемикання реле i, відповідно, зміни навантаження відбувається вимірювання напруги ФМ і напруги на струмовому шунті для визначення сили струму ФМ. Після проходження всіх точок від ХХ до КЗ, програма вимикає всі реле для повернення до режиму XX, i далі починається обробка отриманих даних. Якщо під час вимірювання ВАX паралельно відбувалося отримання даних про інтенсивність сонячної радіації, то програма виконує коригування отриманих даних для приведення їх до одного рівня радіації. Далі за отриманими даними відбувається обчислення параметрів ФМ за методами, розробленими авторами раніше [6,7], а на рис. 2 показаний алгоритм удосконаленого в даній роботі програмного забезпечення.

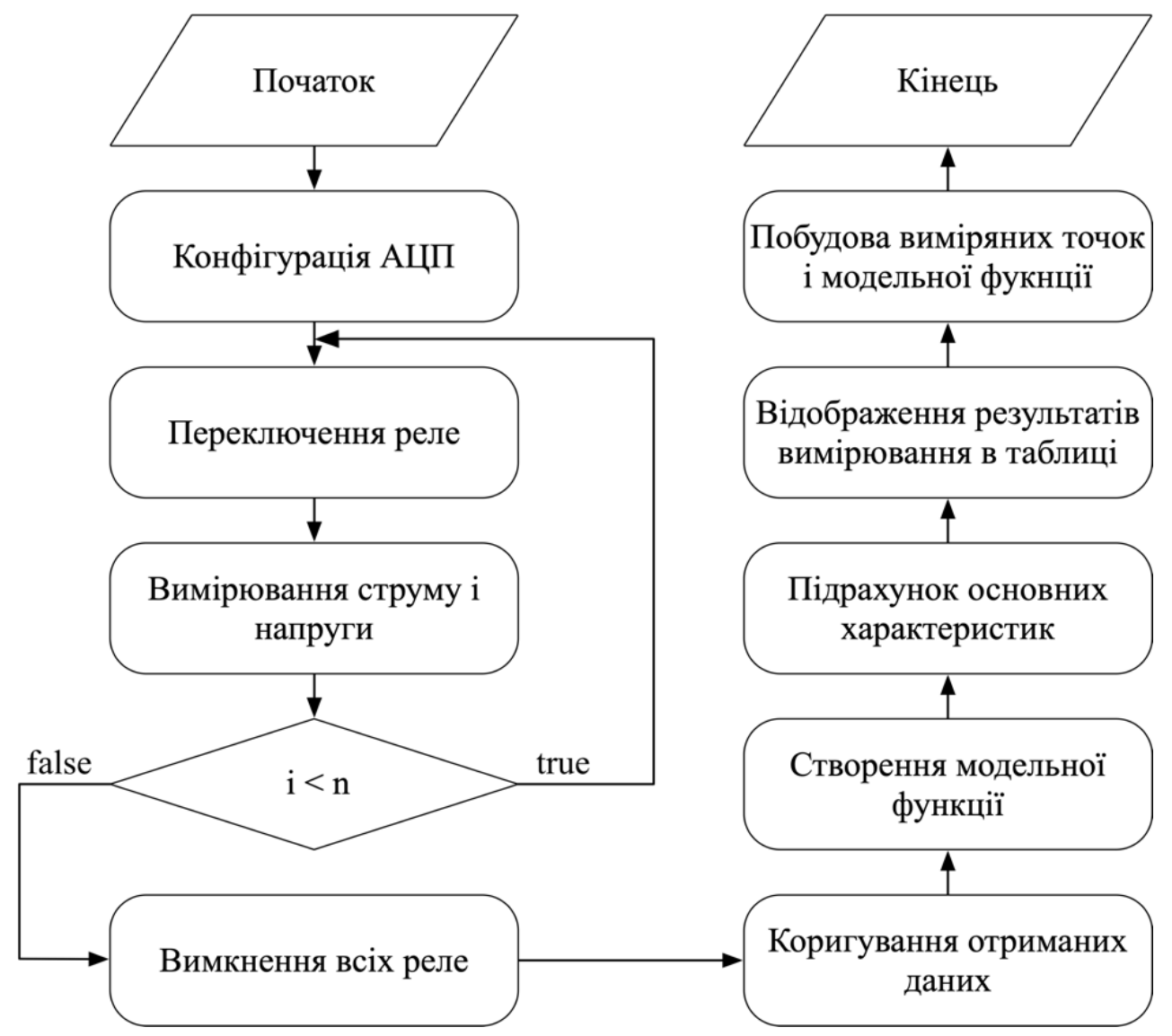

Рис. 2. Алгоритм програми з управління процесами вимірювання і обробки даних

Fig. 2. Algorithm of the program for control of measurement and data processing 
Окремою задачею, яка вирішувалась в цій роботі, було знаходження оптимальної послідовності комбінацій включення резисторів у магазині опорів навантаження, тобто послідовності перемикань реле. Для розробленої електричної схеми існує 26332 комбінацій включення резисторів у навантаження. Це занадто велике число можливих результативних комбінацій замінювалося 724 унікальними відліками на експерименті. Цієї кількості комбінацій опорів достатньо, щоб лінії навантаження (залежності $I(V)$ для активних опорів) щільно покривали площину $I-V$, в якій вимірюється ВАХ фотомодуля (рис. 3).
Особливість роботи зв'язки MATLABArduino полягає в тому, що MATLAB завантажує в контролер спеціальну програму-сервер, яка дозволяє керувати контролером з ПК в режимі реального часу без необхідності перезавантаження програми. Отже, обчислювальна потужність плати обмежується лише потужністю комп'ютера користувача. Це дає змогу використовувати значно складніші програмні засоби й виконувати їх швидше, відразу обчислювати великі масиви даних i використовувати їх для подальшого управління платою.

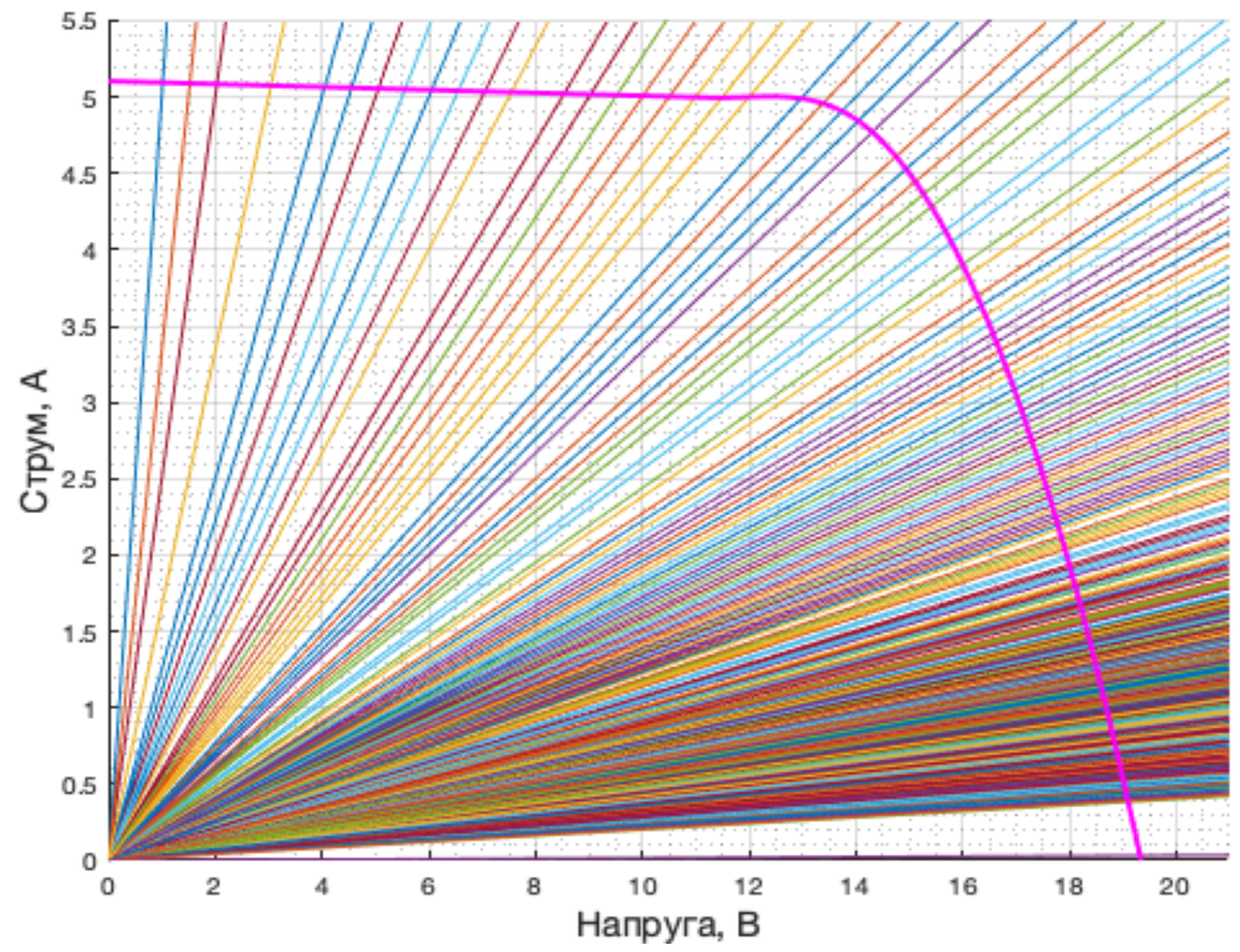

Рис. 3. Лінії навантаження (прямі), які реалізуються при вимірюванні, на тлі типової ВАХ фотомодуля (рожева крива)

Fig. 3. Load lines (straight lines), which are realized during the measurement, against the background of a typical CVC PV module (pink curve)

Збільшення кількості експериментальних даних порівняно з попередніми дослідженнями дозволила детальніше покрити всі зони кривої BAX. На рис. 4 зображено ВАХ для повністю освітленого фотомодуля SunRise SR-100 W. Для цього вимірювання було підібрано 30 значень опору, яке рівномірно покриває криву від КЗ до ХХ. 


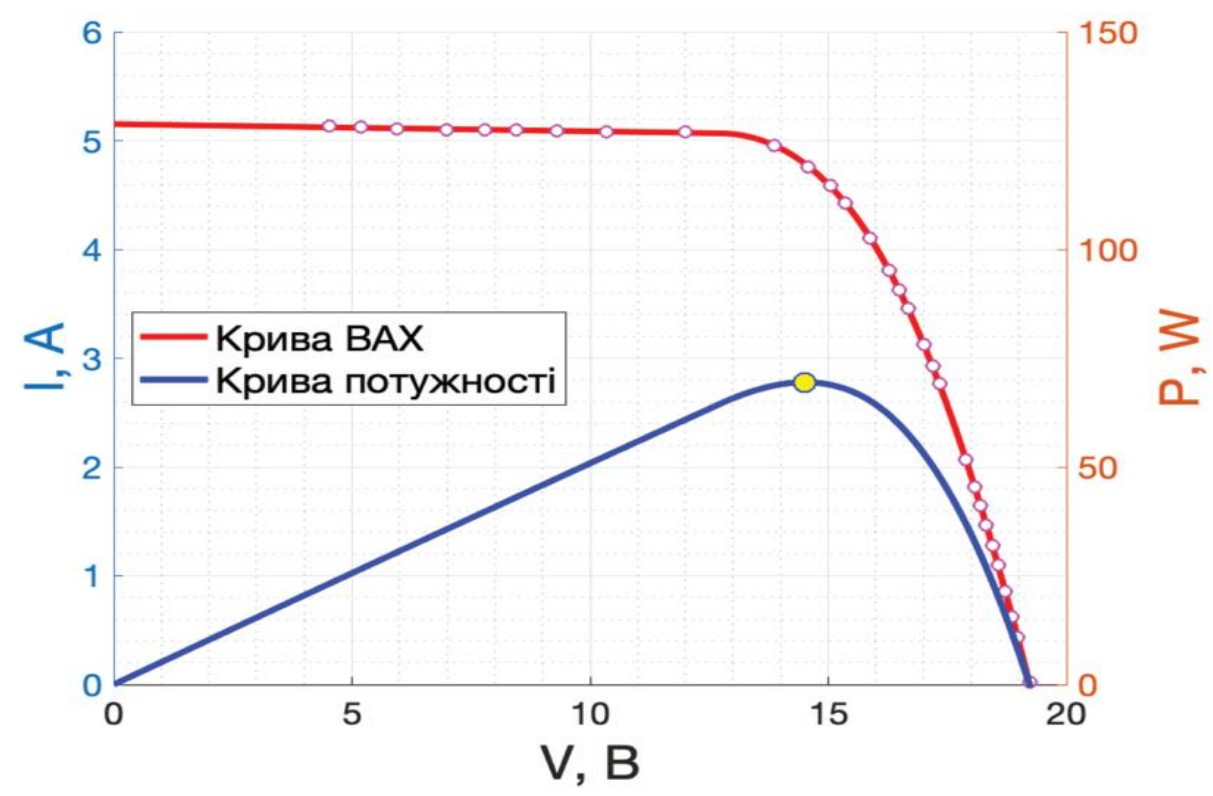

Рис. 4. Вольт-амперна характеристика фотомодуля SunRise SR-100W i крива потужності P (V): експериментальні відліки (точки), апроксимуючі функції (суцільні лінії, червона - I (V), синя - P (V))

Fig. 4. CVC curve of the SunRise SR-100W PV module and power curve $P(V)$ : experiment (points), model function (solid lines, red - I(V), blue - P(V))

Висновки. Реалізація вимірювальної системи для ФМ на основі Arduino і програмного забезпечення, яке написане в MATLAB, дозволяє значно спростити й прискорити проведення вимірювань, реалізувати просту передачу даних на ПК та зручне управління мікроконтролерною платою в режимі реального часу. Завдяки роботі програми на комп'ютері, а не на мікроконтролерній платі вдається значно зменшити час проведення виміру, що позитивно впливає на кінцевий графік, отриманий за нестабільних умов освітлення.

Простий графічний інтерфейс розробленої програми дозволяє легко керувати роботою приладу і відразу переглядати отримані дані 3 $\mathrm{BAX}$, визначити струм короткого замикання, напругу холостого ходу, точку максимуму потужності.

1. Ndiaye A., Charki A., Kobi A. et al. Degradations of silicon photovoltaic modules: A literature review. Solar Energy 96 (2013) 140-151. Syafaruddin and Donald S. Zinger. Review on Methods of Fault Diagnosis in Photovoltaic System Applications. Journal of Engineering Science and Technology Review. 2019. V. 12. No. 5. Pp. 53-66.
2. Кадровый вопрос: энергетике не хватает универсальных специалистов. [Електронний ресурс]. URL: https://realnoevremya.ru/articles/143237--energetike-nehvataet-universalnyh-specialistov

3. IEC 62446. Edition 1.0 2009-05. International standard. Grid connected photovoltaic systems - Minimum requirements for system documentation, commissioning tests and inspection. [Електронний ресурс].

URL: https://solargostaran.com/files/standards/IEC/IEC\%20624 46-2009.pdf.

4. SIST EN 62446:2010. Grid connected PV systems Minimum requirements for system documentation, commissioning tests, and inspection requirements. [Електронний ресурс].

URL: https://standards.iteh.ai/catalog/standards/sist/f0f55437af90-4495-9417-d77d4266844a/sist-en-62446-2010

5. Гаєвськии О.Ю., Іванчук В.Ю., Корнієнко І.О. Система вимірювання параметрів фотоелектричних модулів у реальних умовах експлуатації. Відновлювана енергетика. 2019. № 2 (57). C. 32-39.

6. Гаевская А.Н. Алгоритм аппроксимации вольтамперных характеристик фотомодулей в условиях частичного затенения. Відновлювана енергетика. 2019. № 3 (58). C. 21-29. doi: 10.36296/1819-8058.2019.3(58).21-29.

7. Gaevskii A. Method for Determining Parameters of PV Modules in Field Conditions. 2019 IEEE 6th International Conference on Energy Smart Systems (ESS). Kyiv. Ukraine. 2019. Pp. 205-208. doi: 10.1109/ESS.2019.8764239. 


\section{REFERENCES}

1. Ndiaye A., Charki A., Kobi A. et al. Degradations of silicon photovoltaic modules: A literature review. Solar Energy 96 (2013) 140-151. Syafaruddin and Donald S. Zinger. Review on Methods of Fault Diagnosis in Photovoltaic System Applications. Journal of Engineering Science and Technology Review. 2019. V. 12, No. 5. Pp. 53-66. [in English].

2. Кадровый вопрос: энергетике не хватает универсальных специалистов. [Електронний ресурс]. URL: https://realnoevremya.ru/articles/143237--energetike-nehvataet-universalnyh-specialistov [in Russian].

3. IEC 62446. Edition 1.0 2009-05. International standard. Grid connected photovoltaic systems - Minimum requirements for system documentation, commissioning tests and inspection. [Електронний ресурc].

URL: https://solargostaran.com/files/standards/IEC/IEC\%20624 46-2009.pdf. [in English].

4. SIST EN 62446:2010. Grid connected PV systems Minimum requirements for system documentation, commissioning tests, and inspection requirements. [Електронний ресурс].
URL: https://standards.iteh.ai/catalog/standards/sist/f0f55437af90-4495-9417-d77d4266844a/sist-en-62446-2010.

[in English].

5. Gaevskii A.Y., Ivanchuk V.Y., Kornienko I.O. Systema vymiryuvannya parametriv fotoelektrychnykh moduliv $\mathrm{v}$ realnykh umovakh ekspluatatsiyi. [A system for measurements of the pv module parameters in real operational conditions]. Vidnovluvana energetika. 2019. No. 2 (57). C. 32-39. [in Ukrainian].

6. Gaevskaya A. Algoritm approksimatsii voltampernykh kharakteristik fotomoduley $\mathrm{v}$ usloviyakh chastichnogo zateneniya. [Approximation algorithm for the current-voltage characteristics of PV modules in partial shading conditions]. Vidnovluvana energetika. 2019. No. 3(58). Pp. 21-29. doi: 10.36296/1819-8058.2019.3(58).21-29.

7. Gaevskii A. Method for Determining Parameters of PV Modules in Field Conditions. 2019 IEEE 6th International Conference on Energy Smart Systems (ESS). Kyiv. Ukraine. 2019. Pp. 205-208. doi: 10.1109/ESS.2019.8764239. [in English].

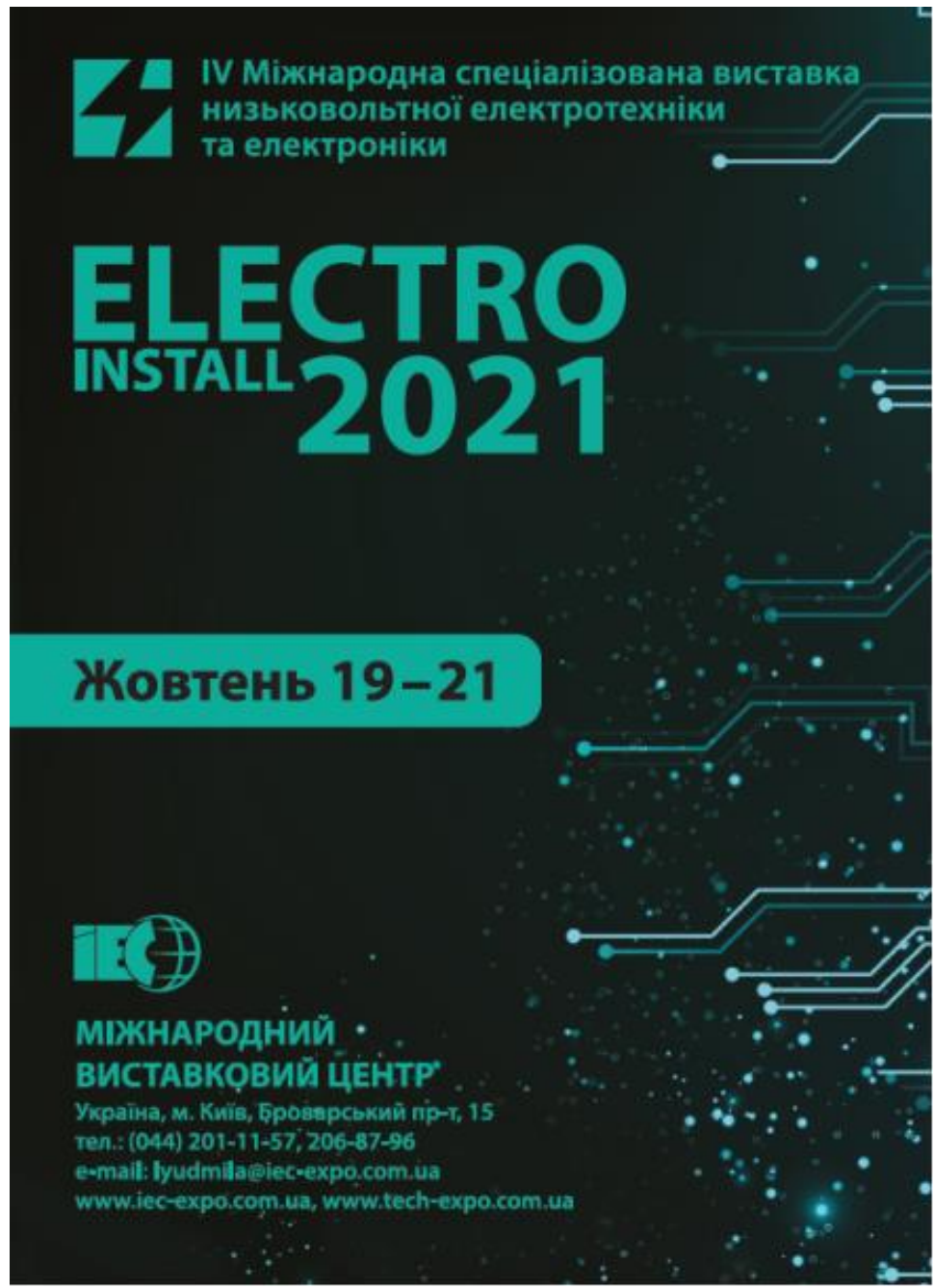

